\title{
Salmonella Outbreak among Railway and Airline Passengers
}

\author{
By Maija Hatakka
}

College of Veterinary Medicine, Department of Food and Environmental Hygiene, Helsinki, and Food and Environmental Laboratory, Vantaa, Finland.

\begin{abstract}
Hatakka, M.: Salmonella outbreak among railway and airline passengers. Acta vet. scand. 1992, 33, 253-260. - A widespread outbreak by Salmonella infantis, infecting a total of 226 people, occurred in Finland at the beginning of August 1986. Of those infected, 107 were railway passengers, 91 were airline passengers and 28 were employed in a food processing establishment. The outbreak among the railway passengers was caused by egg sandwiches, the airline passengers were infected by a meal served on board and the catering employees by the breakfast served in the establishment. The outbreak was caused by food prepared in the establishment's kitchen. The employees' breakfasts had probably been contaminated by an employee who was a symptom-free Salmonella infantis carrier, and a number of the employees subsequently became infected, leading to widespread contamination of the food prepared in the establishment. The spread of the outbreak was further influenced by a heatwave at the time and by shortcomings in the cold storage facilities. The kitchen's hygiene supervision and the quality control of its output were reorganized after the outbreak.
\end{abstract}

travel catering; airline food; food-handling employee; flight kitchen; mass catering; Salmonella infantis.

\section{Introduction}

Very little has been published on food poisoning outbreaks during passenger transport. Tauxe et al. (1987) reported 186 cases of gastroenteritis due to Salmonella enteritidis after 29 flights from Europe to the United States, with an estimated 2,747 people affected. They also analysed 23 reported outbreaks on aircrafts during the period 1947-1984 and found Salmonella to be the most common pathogen. Food prepared by the flight kitchen in Palma de Mallorca and served on a flight between Mallorca and Helsinki was shown to have been the source of a Salmonella enteritidis outbreak (Jahkola 1989).

A widespread Salmonella outbreak in Finland, during which railway and airline pas- sengers became infected, is described and analysed in this paper.

On the 12th of August 1986, the Vantaa Health Authorities were notified of 7 cases by Salmonella infantis. All of those infected had travelled by rail in Finland during the first few days of August and had eaten egg sandwiches which were on sale in the buffet cars. These sandwiches had been prepared by a catering establishment located in Vantaa.

An inspection of the establishment revealed that a number of the food-handling employees had suffered from stomach disorders during the first week of August. The test result obtained on the 12th of August revealed that 
one of the food handlers was infected with S.infantis.

Because the catering prepared airline meals too, careful monitoring of the occurrence of Salmonella infections among airline passengers in Finland was started. One week later the Finnish health authorities were informed that several air passengers had suffered from gastrointestinal illness after a charter flight to Rhodes.

\section{Materials and methods \\ Epidemiologic investigation}

Thirteen railway passengers living in the Helsinki metropolitan area were interviewed by the local health authorities on the 14th and 15th of August by telephone. All had suffered gastroenteritis after travelling by train on the 1st, 2nd or 3rd of August. They were asked about the food they had eaten on the train, the time for onset of the symptoms, the symptoms and the duration of the illness. A wider questionnaire study could not be carried out, because the names of the other passengers were not known.

Standardized questionnaires requesting information on gastrointestinal illness after the Rhodes flight on the 1st of August were sent to all 350 air passengers. They were asked about the symptoms, the onset of the symptoms, the duration of illness and the food eaten during the flight.

A questionnaire was sent to all 162 employees of the catering establishment, requesting information about gastrointestinal illness and exposures to breakfast and lunch served in the staff canteen.

The chi-square test was used for all significance testing.

\section{Laboratory investigation}

Feces samples of airline and train passengers were examined by the local health author- ities for Salmonella by the method of Kelly et al. (1985). The subtyping of the Salmonella species was carried out by the National Salmonella Centre of Finland using the method of Kauffman (1966).

Food samples $(n=153)$ from the catering establishment were analyzed by the Vantaa Food and Environmental Laboratory for Salmonella (Amon. 1986).

The $\mathrm{pH}$ value was measured from the homogenate of $10 \mathrm{~g}$ food mixed with $10 \mathrm{ml}$ of distilled water (Digital-pH-Meter E 632, Metrohm, Switzerland).

The water activity $\left(a_{w}\right)$ was measured according to the method of the Nordic Committee on Food Analysis (Anon.1984) using a hygrometer (Lufft GmbH, Stuttgart, F.R.G.).

\section{Catering establishment inspection}

The Vantaa health authorities inspected the storage of raw materials used in the kitchen, food preparation areas, refrigeration equipment, general cleanliness and repair of equipment. Food preparation methods were checked, especially preparation of egg sandwiches for trains and the meal served on the Rhodes flight.

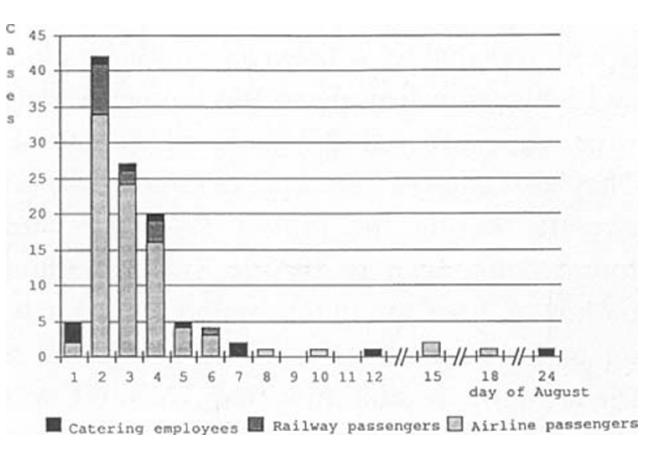

Figure 1. Onset of symptoms of catering employees and of railway and airline passengers infected with Salmonella infantis. 


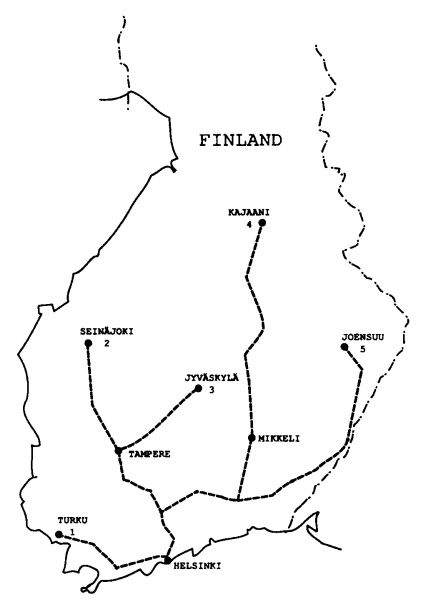

Figure 2. Railway journeys taken by the infected railway passengers in Finland.

\section{Results}

\section{Epidemiologic investigation}

The onset times of the symptoms among passengers and catering employees are shown in Fig. 1. The symptoms of the catering employees began for the most part during the first week of August. Among passenger groups symptoms began mostly between the 2nd and the 4th of August.

According to data obtained from the interview with the 13 railway passengers and to data obtained from the National Salmonella Centre of Finland, the infected railway passengers had taken 5 different railway journeys; all of them had departed from Helsinki (Fig. 2). They had travelled on the 1st, 2nd or 3rd of August, and all had eaten egg sandwiches purchased from the buffet cars. Altogether 600 egg sandwiches had been prepared for trains for the above-mentioned period. The incubation period varied from 18 to $70 \mathrm{~h}$, the median was $30 \mathrm{~h}$. The symptoms are shown in Table 1 . The main symptoms were diarrhoea and high fever. Finnish health authorities reported that 10 infected railway passengers required hospitalization. The duration of illness varied from 3 to 30 days, the median was 11 days.

Two hundred and ten (60\%) of the 350 air passengers returned the questionnaires. Fifty two $(25 \%)$ answered that they had gastrointestinal illness after the flight. The incubation period varied from 4 to $132 \mathrm{~h}$, the median was $44 \mathrm{~h}$. The symptoms are shown in Table 1. The main symptoms were diarrhoea and vomiting. The symptoms in this group were milder than in the railway passenger group. The duration of illness varied from 1 to 10 days, the median was 4 days. The meal served on the aircraft consisted of Viennese

Table 1. Distribution of symptoms among railway passengers, catering establishment's employees and airline passengers.

\begin{tabular}{|c|c|c|c|c|c|c|}
\hline \multirow[t]{2}{*}{ Symptom } & \multicolumn{2}{|c|}{$\begin{array}{c}\text { Railway } \\
\text { passengers }\end{array}$} & \multicolumn{2}{|c|}{$\begin{array}{l}\text { Establishment's } \\
\text { employees }\end{array}$} & \multicolumn{2}{|c|}{$\begin{array}{c}\text { Airline } \\
\text { passengers }\end{array}$} \\
\hline & $\mathbf{N}$ & $\%$ & $\mathbf{N}$ & $\%$ & $\mathbf{N}$ & $\%$ \\
\hline Diarrhoea & 13 & 100 & 8 & 73 & 41 & 78 \\
\hline Fever & 10 & 77 & 4 & 36 & 15 & 29 \\
\hline Vomiting & 4 & 31 & 4 & 36 & 31 & 60 \\
\hline Joint pains & 3 & 23 & 0 & 0 & 0 & 0 \\
\hline Headache & 1 & 8 & 2 & 18 & 38 & 54 \\
\hline Total & 13 & & 11 & & 52 & \\
\hline
\end{tabular}

$\mathrm{N}$ : number of people. 
Table 2. The number of railway and airline passengers and catering establishment's employees at risk and the number of persons infected in different groups.

\begin{tabular}{lccc}
\hline & $\begin{array}{c}\text { Number of } \\
\text { persons } \\
\text { at risk }\end{array}$ & $\begin{array}{c}\text { Number of } \\
\text { infected } \\
\text { persons }\end{array}$ & $\begin{array}{c}\% \\
\text { infected }\end{array}$ \\
\hline $\begin{array}{l}\text { Railway } \\
\text { passengers }\end{array}$ & $600 *$ & 107 & 18 \\
$\begin{array}{l}\text { Airline } \\
\text { passengers }\end{array}$ & 350 & 91 & 26 \\
$\begin{array}{l}\text { Catering } \\
\text { establishment's } \\
\text { employees }\end{array}$ & 162 & 28 & 17 \\
\hline Total & 1112 & 226 & \\
\hline
\end{tabular}

* Estimated on the basis of number of sandwiches sold.

goulash, fresh salad and Swiss roll. Statistical analysis showed that no single dish was associated with the illness.

One hundred and thirty three $(82 \%)$ catering establishment's employees returned the questionnaire. Eleven (7\%) experienced gastrointestinal illness during August. The symptoms are shown in Table 1 . The main symptom was diarrhoea. The symptoms were milder than among the passenger's group. The duration of the illness was 2-3 days. According to the questionnaire, most of the employees ( $82 \%$ ) ate breakfast in the staff canteen regularly, whereas only $21 \%$ lunched there. All infected employees had eaten breakfast and statistical analysis proved that the infection was associated with eating breakfast $(\mathrm{p}<0.05)$. No statistically significant connection was established between origin of lunch and the infection.

\section{Laboratory investigations}

Feces samples. According to the National Salmonella Centre of Finland, on the basis of microbiological investigations, a total of 226 persons became infected with $S$. infantis during this outbreak. The numbers of infected persons in different groups were 107 railway passengers, 91 airline passengers and 28 catering establishment's employees. The number of persons at risk and the number of persons infected are shown in Table 2. In the group of railway passengers the maximum possible number of people at risk was 600 , which was the number of egg sandwiches prepared for trains.

Of the catering establishment's employees 28 $(17 \%)$ became infected. The test results indicated that the infection had spread to almost every group of employees (Table 3). Eleven (7\%) had symptoms. Out of the 118 food handlers, $23(19 \%)$ became infected, 17 were symptom-free carriers and only 6 had symptoms. The highest \% of infected persons was in the bakery, and the highest amount of infected persons in the cold kitchen (Table 3).

Food samples. The airline dishes prepared by the catering establishment were regularly sampled for microbiological tests. On the 12th of August $S$. infantis was detected in 1 of the 2 hot meal samples. The samples were heat-processed, deep-frozen airline meals representing a batch with 1200 portions. The portions were prepared on the 30th of July for charter flights.

During the inspection of the catering establishment between the 12th and 15th of August a total of 148 food samples were taken for laboratory analysis. The samples were cooked egg products, raw chicken products, cold cuts and Swiss rolls sliced in the cold kitchen. All samples were negative for Salmonella.

Airline meals corresponding to the menu served on the flight to Rhodes were prepared in the kitchen. The meals, Viennese goulash, 
fresh salad and Swiss roll were analysed. Salmonella bacteria were not detected in these 3 types of samples. The $\mathrm{pH}$ value of the salad was 4.7 that of the Swiss roll ranged between 4.1 and 4.6. The $a_{w}$ value of the Swiss roll was 0.87 .

\section{Catering establishment inspection}

The catering facilities are located in an old building and are not planned for food processing. They have a fairly wide range of operations, including a kitchen for cold foods, a kitchen for hot foods and bread and pastry bakeries. The sandwiches for sale on trains were prepared in the cold kitchen. The dishes for the Rhodes flight were prepared in the cold and hot kitchens. The transport routes for raw and cooked foods were not separated, thus resulting in a risk of crosscontamination. In addition, high-risk raw materials such as raw poultry were used.

The inspection on the 12th of August revealed that a number of food handlers had suffered from gastrointestinal illness during the first week of August. Three food handlers had simultaneously experienced the first symptoms of diarrhoea on the 1st of August. They had contacted their industrial health- department. They were not forbidden to continue food-handling and they were not given any instructions concerning handling of foods or improving personal hygiene. The first positive test result on the 12th of August first showed that there was $S$. infantis infection among food handlers.

The period from 27 July - 6 August was unusually hot in Finland. The maximum average temperature, measured at the Helsinki-Vantaa airport near the location of the catering, was $24.6^{\circ} \mathrm{C}$ (range 21.9 to $28.2^{\circ} \mathrm{C}$ ). There was neither temperature monitoring system nor equipment to reduce the temperature in the cold kitchen.

The egg sandwiches served on the trains had been prepared in the cold kitchen during 3 days, on the 31st of July and the 1st and 2nd of August. They had been refrigerated and stored at a temperature of $+4^{\circ} \mathrm{C}$. In the mornings the sandwiches had been transported a distance of $20 \mathrm{~km}$, to Helsinki railway station, in an unchilled vehicle. Their subsequent storage and serving temperatures have proved impossible to verify. Airline meals for the Rhodes flight on the 1st of August were also transported in unchilled vehicles and it was impossible to verify

Table 3. Distribution of those infected with Salmonella infantis between the different catering departments.

\begin{tabular}{lllll}
\hline $\begin{array}{l}\text { Catering } \\
\text { departments }\end{array}$ & $\begin{array}{l}\text { Number of } \\
\text { employees }\end{array}$ & & \multicolumn{2}{c}{ Number of infected } \\
\cline { 3 - 5 } & With symptoms & Symptom-free & Total & $\%$ \\
\hline
\end{tabular}

Food-handling departments

\begin{tabular}{lrrrrr} 
Kitchen for cold foods & 45 & 1 & 8 & 9 & 20 \\
Kitchen for hot foods & 27 & 1 & 3 & 4 & 15 \\
Bakery & 21 & 2 & 6 & 8 & 38 \\
Pastry bakery & 5 & 0 & 0 & 0 & 0 \\
Packing & 20 & 2 & 0 & 2 & 10 \\
Subtotal & 118 & 6 & 17 & 23 & 19 \\
nts & 44 & 5 & 0 & 5 & 11 \\
\hline
\end{tabular}


where the meals had been stored at the airport.

The breakfast served in the catering establishment consisted of foods used in production and prepared in the cold kitchen. The foods were kept at room temperature for the $2 \mathrm{~h}$ breakfast period.

\section{Preventive control measures}

Two nationwide statements, on the 15th and the 21st of August, were issued to establish the scope of the outbreak. The purpose of the statements was to inform passengers that the source of infection might have been the food served on traffic vehicles. Passengers were requested to contact the local health authorities so that any possible infections could be verified in laboratory tests.

A thorough cleansing and disinfecting of the catering establishment was ordered by the local health authorities on the 12th of August. The use of disposable gloves in the cold kitchen was recommended. Also the transport of waste food to a pig farm was forbidden.

Test results of the catering establishment's employees on the 15th of August showed that 17 employees had been infected with Salmonella. Discussions between the management and the local health authorities then led to the decision to close the catering. The catering remained closed for 10 days. Repair work was carried out, surfaces were painted, floors repaired and the building was finally thoroughly cleaned and disinfected. The transport routes for raw and prepared foods were reorganized. The use of high-risk raw materials was forbidden. The catering manager decided to destroy all frozen airline meals prepared during July and August.

It was stipulated that the temperature in the cold kitchen may never exceed $18^{\circ} \mathrm{C}$ and a daily temperature control was demanded.
Three new cold stores were installed, signifying a considerable increase in the amount of cold storage. A rapid cooling facility was installed in the hot kitchen. The water taps at hand-washing points were replaced to prevent them from aiding the spread of infection. All infected food handlers were forbidden to handle food. They were permitted to resume work after 5 consecutive Salmonella negative samples. The periods of absence were, on average, 5 weeks.

Three training sessions dealing with foodborne illnesses were held for the food-handling personnel during August 1986. Special emphasis was placed on personal hygiene and the correct storage of foods.

As a consequence of the outbreak, the company recruited a hygiene advisor, responsible for hygiene and employee training in the catering establishment.

\section{Discussion}

During 1986, Salmonella bacteria caused 17 outbreaks in Finland, involving a total of 710 people (Hirn et al. 1989). The outbreak described here was the largest, and it spread to many parts of Finland.

It has been impossible to establish the origin of the outbreak. Raw materials used in the establishment were tested and they were negative for Salmonella. It is probable that 1 of the food-handling employees of the catering establishment became infected during July. Because none of the employees had been abroad recently, the infection was probably of Finnish origin. Salmonella bacteria are very seldom found in Finnish foodstuffs, excluding poultry. In studies carried out on samples from frozen broilers on sale in Finland, $10 \%$ were contaminated with Salmonella bacteria (Nurmi \& Schildt 1987). The main cause of Salmonella infections in poultry in 1986 was $S$. infantis, which was respon- 
sible for $84 \%$ of the infections (Anon. 1988). The source of infection could thus have been broiler, from which the Salmonella infection due to unhygienic treatment might have been spread to other foods.

The infected symptom-free carrier probably contaminated the breakfast, sliced cold cuts and bread in the cold kitchen. The breakfast was served at room temperature for a period of $2 \mathrm{~h}$. Since there was a heatwave at this time, Salmonella bacteria could have grown rapidly in the cold cuts. The infection spread via the breakfast to the catering establishment's employees. Food handlers contaminated the products of the kitchen, causing the infection to spread to the passengers.

The infection spread to food-handling departments of the establishment, except the pastry bakery. The highest percentage of infected food handlers was in bakery. In the cold kitchen, where the breakfast was prepared, 9 infected persons were working, and only 1 of them had symptoms. Because the food handlers did not know about the hazard of the spreading infection, the risk of products becoming contaminated was manifold. If the industrial health department had immediately in the beginning of August started to investigate the origin of the gastrointestinal illness of the food handlers, the wide spread of contamination of the products could possibly have been prevented.

The contamination of the egg sandwiches together with their transport in unchilled vehicles, their uncontrolled storage prior to transfer to the trains and the insufficient cold storage facilities in the trains, all enabled proliferation of the $S$. infantis. The severity of the symptoms of the railway passengers suggested high counts of $S$. infantis in the sandwiches. The mildness of the symptoms of the catering establishment's employees suggests that the temperature abuse occuring during the breakfast was relatively short, thus resulting in a lower degree of contamination.

According to information received, the hot meal served during the flight to Rhodes was heated at $175^{\circ} \mathrm{C}$ for a period of $20 \mathrm{~min}$. This heat treatment is sufficient to destroy any surface contamination. However, it may be possible that there was some malfunction with the oven used on the aircraft, so that the heat treatment remained insufficient to destroy Salmonella bacteria. The $\mathrm{pH}$ and $\mathrm{a}_{\mathrm{w}}$ values of the Swiss roll were low enough to prevent the proliferation of Salmonella bacteria. The fresh salad was made of tomato, cucumber and lettuce. The cause of the infection of the airline passengers may have been the fresh salad too. Asplund \& Nurmi (1991) have reported that $S$. infantis grew in tomatoes, from cell densities of $10^{2}$ to $10^{6}$ $\mathrm{cfu} / \mathrm{g}$ (coloniforming units/gram), at $22^{\circ} \mathrm{C}$ for $24 \mathrm{~h}$. The degree of contamination of the salad was apparently lower than that of the sandwiches eaten by the railway passengers, since the airline passengers had milder symptoms. The kitchen had prepared meals for many flights during the beginning of August. However, passengers became ill only after a single flight. This can be explained by the unrefrigerated period of the portions before reaching the aircraft or failing of the heat treatment of hot meals on this particular flight.

On the basis of microbiological investigations carried out, 226 infected persons were reported in Finland. Information about the epidemic was not received until almost 2 weeks after its outbreak. It was estimated that $17-26 \%$ of those at risk became infected. Since there was a considerable delay in the collection of samples, it is probable that some people who had been exposed were already cleared of the infection. The number 
of infected persons may therefore have been considerably higher than official figures suggest.

Owing to the outbreak, the catering establishment suffered much adverse publicity and financial losses estimated to be in the region of FIM 5.1 mill. (Pakkala 1989). The largest category of expences were medical costs and sick leave.

Strict hygiene requirements must be enforced during the preparation, transport and serving of food in transit and especially on aircraft. This outbreak demonstrates the importance of close co-operation between food-handling employees, their industrial health department and local health authorities. In addition, the health department should be aware of the special risk factors present in different fields of food handling.

\section{References}

Anonymous: Water activity. Measuring with a polyamide filament hygrometer. Nordic Committee on Food Analysis. Nr 104, 1984.

Anonymous: Salmonella bacteria. Detection in foods. Nordic Committee on Food Analysis. $\mathrm{Nr}$ 71, 1986.

Anonymous: Veterinary Service 1985-1986. Ministry of Agriculture and Forestry. Veterinary Department. Report. Helsinki 1988, 46 pp.

Asplund K, Nurmi E: The growth of Salmonella in tomatoes. Int. J. Food Microbiol. 1991, 13, 177182.

Hirn J, Aho M: Ruokamyrkytystilanteemme. (Facts about the foodborne outbreaks in Finland). Suom. Eläinlääkäril. 1988, 95, 467-472.

Jahkola M: Salmonella enteritidis outbreak traced to airline food. WHO Surveillance Programme for Control of Foodborne Infections and Intoxications in Europe, Newsletter 1989, $22,3$.

Kauffman F: The Bacteriology of Enterobacteriaceae. Munksgard, Copenhagen 1966, 400 pp.
Kelly MT, Brenner DJ, Farmer III JJ: Enterobacteriaceae. In: Lennette EH, Balows A, Hausler Jr WJ, Jean Shadomy H (Eds.): Manual of Clinical Microbiology. 4th ed. Amer. Soc. Microbiol. Washington D.C. 1985, 263-267.

Nurmi E, Schildt $R$ : Hyötyeläinten salmonellatartunnat ja niiden ehkäisy. (Salmonella infections in domestric animals, and their prevention). Elintarvike ja terveys 1987, 3, 34-43.

Pakkala P: Ruokamyrkytysten aiheuttamat kustannukset. (Costs caused by food poisoning outbreaks). Proc. Ann. Meet. Finnish Vet. Ass., Helsinki, 1989, 125-133.

Tauxe RV, Torney MP, Mascola L, Hargrett-Bean NT, Blake PA: Salmonellosis outbreak on transatlantic flights: Foodborne illness on aircraft 1948-1984. Amer. J. Epid. 1987, 125, 150-157.

\section{Sammanfattning \\ Salmonella epidemi bland tåg- och flygpassagerare. I början av augusti 1986 utbröt en för finländska förhållanden omfattande Salmonella infantis epide- $\mathrm{mi}$, som berörde hela landet, där 226 personer smittades. Av dem som fick smittan var 107 tågrese- närer, 91 flygresenärer samt 28 anställda vid en anläggning för livsmedelsproduction. Tågresenärer- na smittades av äggsmörgåsar, flygresenärerna av en måltid ombord på planet och livsmedelspersona- len av ett morgonmål som framställts och serverats på arbetsplatsen. Uppenbarligen var det en symp- tomfri Salmonella infantis smittad arbetstagare som överförde smittan till personalen. Följden blev en omfattande kontamination av anläggningens pro- ducter. Det varma vädret och brister i kylförvarin- gen bidrog också till epidemins utbrott. Övervak- ningen av hygienen på anläggningen har omorgani- serats efter epidemin.}

\section{Acknowledgements}

The author would like to thank Ms. Annikki Silander and Ms. Kirsti Järvinen, and the staff of the Food and Environmental Laboratory of the City of Vantaa for technical assistance, and Professor Hannu Korkeala for valuable criticism of the manuscript.

(Received June 13, 1991; accepted March 15, 1992).

Reprints may be requested from: M. Hatakka, Food and Environmental Laboratory, Viertolankuja 4A, SF-01300 Vantaa, Finland. 